\title{
Strain Improvement of Trichoderma Viride through Mutation for Enhanced Production of Cellulase
}

\author{
Nusrat Khandoker ${ }^{1}$, Arafat Al Mamun², Tanvir Noor Nafiz ${ }^{1}$, Shakila Nargis Khan ${ }^{1}$ and Md. Mozammel Hoq ${ }^{1 *}$ \\ ${ }^{1}$ Department of Microbiology, University of Dhaka, Dhaka-1000, ${ }^{2}$ Centre for Advanced Research in Sciences (CARS), \\ University of Dhaka, Dhaka-1000.
}

\begin{abstract}
Microbial fungal cellulases are very important for their applications in biopolishing of textile fibres, in poultry feed and paper and pulp industries. The main purpose of this study was to improve the wild strain Trichoderma viride for enhanced production of cellulase by random mutation technique employing ultraviolet (UV) irradiation and Ethidium bromide (EtBr) treatments. The wild strain exhibited the highest cellulase activity $5.52 \mathrm{U} / \mathrm{ml}$ on carboxy methyl cellulose $(1.0 \%)$ and a comparable activity $4.74 \mathrm{U} / \mathrm{ml}$ on wheat bran $(1.0 \%)$ as substrate under the optimum temperature $30^{\circ} \mathrm{C}$ and $\mathrm{pH} 4.0$. Upon mutation by $\mathrm{UV}$ exposure the fungi produced cellulase $11.28 \mathrm{U} / \mathrm{ml}$ where as EtBr treated mutant showed $14.61 \mathrm{U} / \mathrm{ml}$ cellulase activities. Both the enzymes from wild and mutant $T$. viride demonstrated the highest activity at the assay temperature of $40^{\circ} \mathrm{C}$. The enzyme was applied for bio-polishing of jeans at prototype experiment and showed effective result as compared to one of the commercial enzymes.
\end{abstract}

Key words: Trichoderma viride, Cellulase, Biopolishing.

\section{Introduction}

Microbial cellulase finds applications in various industries and constitutes a major group of the industrial enzymes. ${ }^{1}$ Cellulases are used widely in the textile industry for cotton softening and biopolishing; in the detergent market for color care, cleaning, and anti-deposition; in the food industry for mashing and in the pulp and paper industries for de-inking, drainage improvement, and fiber modification ${ }^{2-3}$. In textile industry, biopolishing removes the protruding fibers of a fabric through the selective action of cellulase.

Many microorganisms that produce various cellulolytic enzymes have been studied for several decades. The genus of Trichoderma has been especially famous for producing cellulolytic enzymes with relatively high enzymatic activity ${ }^{4}$. Among them Trichoderma viride is easy and inexpensive to cultivate for production of cellulase $^{5}$. T. viride is considered to be a safe production organism, because it is non-pathogenic to healthy humans and does not produce mycotoxins or antibiotics under the conditions used for enzyme production ${ }^{6-7}$.

Economic analyses have indicated that the production of cellulase is still a cost factor. It is therefore imperative to improve the production of cellulase in order to make the process more economically viable ${ }^{8}$. Hence many traditional mutagenesis strategies have been applied to improve the production of cellulase $^{9}$. This technique is simple and successful many times as compare to the complication exists.

The objective of this study was optimization of parameters for production of cellulase by $T$. viride and mutation of the fungi for enhanced production of cellulase and application of the enzymes for biopolishing.

\section{Methods and materials}

Fungi

Trichoderma viride used in this study was obtained from Bangladesh Jute Research Institute (BJRI). The fungal culture was maintained on Potato Dextrose Agar (PDA) slant at $4^{\circ} \mathrm{C}$ and sub-cultured twice a month.

Cultivation of $T$. viride for cellulase production

T. viride was inoculated on Potato Dextrose Agar (PDA) medium and incubated at $30^{\circ} \mathrm{C}$ for 5 days. After sporulation of green conidia, a square portion $(1 \mathrm{~cm} \mathrm{x} 1 \mathrm{~cm})$ medium containing fungal mycelia and spore was inoculated into $100 \mathrm{ml}$ fermentation medium composed of Mendel's salt solution in a $250 \mathrm{ml}$ Erlenmeyer flask and incubated at $30^{\circ} \mathrm{C}$ and $120 \mathrm{rpm}$ in an orbital shaker. The mass concentration of nutrients in Mendel's salt solution is: Urea $0.3 \mathrm{~g} / \mathrm{L}$, $\left(\mathrm{NH}_{4}\right)_{2} \mathrm{SO}_{4} 1.4 \mathrm{~g} / \mathrm{L}, \mathrm{KH}_{2} \mathrm{PO}_{4} 2.0 \mathrm{~g} / \mathrm{L}, \mathrm{CaCl}_{2} 0.3 \mathrm{~g} / \mathrm{L}, \mathrm{MgSO}_{4} 0.3 \mathrm{~g} / \mathrm{L}$, yeast extract $0.25 \mathrm{~g} / \mathrm{L}$ and peptone $0.75 \mathrm{~g} / \mathrm{L}$ with $10 \mathrm{~g} / \mathrm{L}$ of carboxymethyl cellulose (CMC) in $0.05 \mathrm{M}$ citrate buffer. After fungal growth, culture broth was collected and centrifuged at 6,000 rpm for 15 minutes and the supernatant was used as crude enzyme.

Optimization of culture conditions for enzyme production

For optimization of cultural conditions for cellulase production by $T$. viride, the parameters such as incubation period, initial $\mathrm{pH}$ of fermentation medium, incubation temperature and effect of various carbon sources were taken into concern. 
Effect of incubation period on enzyme production by T. viride:

Fermentation period is an important parameter for enzyme production by fungi. In this study, fermentation was carried out up to 6 days and production rate was measured at $24 \mathrm{hr}$ intervals to find the optimum incubation period.

Effect of initial pH of fermentation medium on enzyme production by T. viride:

For evaluation of the effect of initial culture $\mathrm{pH}$ on enzyme production, the fungus $T$. viride was cultivated in enzyme production medium with different initial $\mathrm{pH}$ values (4.0-6.0) at $30^{\circ} \mathrm{C}$ and $120 \mathrm{rpm}$.

Effect of temperature on enzyme production by T. viride:

To evaluate the effect of temperature on enzyme production, the fungus $T$. viride was cultivated in enzyme production medium with $\mathrm{pH} 4.0$ and incubated at different temperature values $\left(25^{\circ} \mathrm{C}\right.$, $30^{\circ} \mathrm{C}, 35^{\circ} \mathrm{C}, 40^{\circ} \mathrm{C}$ and $45^{\circ} \mathrm{C}$ ) and $120 \mathrm{rpm}$.

Effect of various carbon sources on enzyme production by $T$. viride:

Various carbon sources namely carboxymethyl cellulose (CMC), lactose and some cheap substrates such as rice bran, wheat bran were used in the media with $\mathrm{pH} 4.0$ to study their effect on enzyme production. After inoculation the fermentation media were incubated at $30^{\circ} \mathrm{C}$ and $120 \mathrm{rpm}$.

Method of mutation of $T$. viride

In an attempt to enhance enzyme production potential of the $T$. viride, mutation was carried out with classical mutagenic agents like ultraviolet (UV) irradiation and chemical mutagen i.e Ethidium bromide (EtBr).

\section{UV mutagenesis}

Ten milliliters of conidial suspension $\left(5 \times 10^{5}\right.$ conidia/ml) from one week-old PDA culture was transferred to the sterilized Petri plates and exposed to ultraviolet irradiation for $40 \mathrm{~min}$ with $5 \mathrm{~min}$ time interval under UV lamp having a wavelength of $254 \mathrm{~nm}$ with $220 \mathrm{~V}$ at $50 \mathrm{~Hz}$. The distance between lamp and suspension was adjusted to $20 \mathrm{~cm}$ for each trial. After the time intervals, $200 \mu \mathrm{l}$ of the conidial suspension was transferred to the Petri plates containing colony restrictor medium. (Colony restrictor medium is composed of PDA medium with the addition of $0.1 \%$ Triton X100 and $0.1 \%$ L-Sorbose as colony restrictors). Plates were then incubated at $30^{\circ} \mathrm{C}$ to obtain isolated colonies.

\section{Chemical mutagenesis}

The organism grown on PDA plate was scraped off into sterile phosphate buffer $(0.02 \mathrm{M}$ and $\mathrm{pH}$ 7.0) containing Tween-80 (1:5000) to give uniform suspension. The suspension was transferred into a sterile conical flask and thoroughly shaken for 30 mins on a rotary shaker to break the spore chains. The spore suspension was then filtered through a thin sterile cotton wad into a sterile tube. Then $4 \mathrm{ml}$ of spore suspension from the sterile tube was added to $2 \mathrm{ml}$ of EtBr solution $(10 \mu \mathrm{l} / \mathrm{ml})$. $1 \mathrm{ml}$ of this solution was taken after $24 \mathrm{hrs}$ and centrifuged immediately and the supernatant solution was decanted. Spores were washed three times with sterile water and resuspended in $10 \mathrm{ml}$ of sterile phosphate buffer. The samples were serially diluted in the same buffer and spread plated over colony restrictor medium. Then it was incubated at $30^{\circ} \mathrm{C}$ to obtain isolated colonies.

Screening of the mutants of $T$. viride

The isolated colonies from colony restrictor plates were grown on the plate- screening medium containing Mendel's mineral salt solution that is: Urea $0.3 \mathrm{~g} / \mathrm{L},\left(\mathrm{NH}_{4}\right)_{2} \mathrm{SO}_{4} 1.4 \mathrm{~g} / \mathrm{L}, \mathrm{KH}_{2} \mathrm{PO}_{4} 2.0 \mathrm{~g} / \mathrm{L}$, $\mathrm{CaCl}_{2} 0.3 \mathrm{~g} / \mathrm{L}, \mathrm{MgSO}_{4} 0.3 \mathrm{~g} / \mathrm{L}$, yeast extract $0.25 \mathrm{~g} / \mathrm{L}$ and peptone $0.75 \mathrm{~g} / \mathrm{L}$ with $10 \mathrm{~g} / \mathrm{L}$ of cellulose and $17.5 \mathrm{~g} / \mathrm{L}$ agar. After incubation at $30^{\circ} \mathrm{C}$ for 3 days plates were flooded with $0.1 \%$ congo red solution and left for 15 minutes with intermittent shaking. Then plates were destained with $1 \mathrm{M} \mathrm{NaCl}$ solution. The $\mathrm{NaCl}$ solution eluted the dye in the clearing zone where the cellulase was degraded into simple sugar. The mutants those produced significant clearing zone were transferred onto PDA medium and incubated at $30^{\circ} \mathrm{C}$ for 5 days. After conidial formation, it was transferred into fermentation medium for cellulase production.

\section{Enzyme assay}

Carboxymethyl cellulase (CMCase) activity was estimated essentially according to IUPAC instructions ${ }^{11}$ using $1 \%$ solution of carboxylmethyl cellulose in $0.05 \mathrm{M}$ citrate buffer, $\mathrm{pH} 5.0$ as substrate. $0.5 \mathrm{ml}$ of appropriately diluted enzyme solution was added to $1.0 \mathrm{ml}$ of the substrate solution and incubated at $50^{\circ} \mathrm{C}$ for $30 \mathrm{~min}$. The reaction was stopped by adding $3.0 \mathrm{ml}$ DNS reagent and the liberated reducing sugar was estimated by the method of Miller ${ }^{12}$. One CMCase unit is the amount of enzyme necessary to produce $1.0 \mu \mathrm{mol}$ reducing sugar as glucose equivalents per min under the standard assay condition.

Effect of assay temperature on enzyme activity:

The optimum temperature for the enzyme activity was measured by incubating the enzyme with the substrate at various temperatures ranging from $30^{\circ} \mathrm{C}$ to $75^{\circ} \mathrm{C}$.

\section{Application of the crude cellulase in biopolishing}

Potentiality of the Trichoderma viride cellulase in biopolishing was compared with a commercial biopolishing enzyme. For this purpose, a commercial enzyme used for biopolishing and nonpolished jeans cloth were collected from a local washing company named Tex-Wash, Dhaka. The enzyme activity of both commercial and the Trichoderma enzymes was determined. The jeans was cut into 6" x 6 " pieces. Then both enzymes in an amount with same strength were subjected to prototype application for biopolishing of jeans in the same condition $\mathrm{pH} 4.0$ and $40^{\circ} \mathrm{C}$ in presence of water for $1 \mathrm{hr}$.

\section{Results and Discussion}

Effect of incubation period on enzyme production by T. viride

The incubation period is directly related with the production of enzyme and other metabolites up to a certain extent. The 
incubation period to achieve maximum cellulase activity (5.52 U/ $\mathrm{ml}$ ) by the wild type Trichoderma viride was 2 days (Figure 1). Different incubation time for peak cellulase production were found for different strains ${ }^{13-14}$. Subsequent increase beyond the optimum incubation period resulted into a decrease cellulase activity. The decrease was always found to be associated with depletion of nutrients or accumulation of some autotoxic products of organism in the media ${ }^{15-16}$. Other related factors, such as the nature of the microorganism and the physiological conditions of the media, are also considered to be important during enzyme production $^{17-18}$.

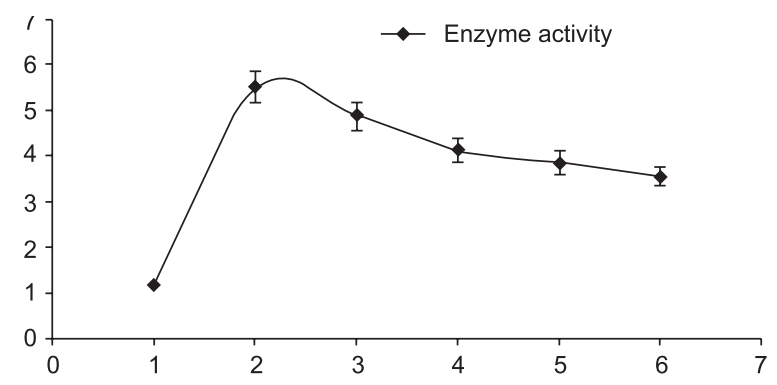

Figure 1. Effect of incubation period on cellulase production by $T$. viride.

\section{Effect of pH on enzyme production by T. viride}

Cellulase yield by Trichoderma viride appears to depend on initial culture pH value. Results illustrated by Figure 2 clearly show that cellulase production, expressed as enzyme activity, gradually increased as the $\mathrm{pH}$ value increased from 3.0 to 4.0 and reached its maximum at $\mathrm{pH} 4.0$ being cellulase activity $6.84 \mathrm{U} / \mathrm{ml}$. The enzyme activity gradually decreased when further increasing the $\mathrm{pH}$. This result is supported by many researchers who found that the cellulase production by Trichoderma spp. is favored by acidic $\mathrm{pH}^{19-20}$.

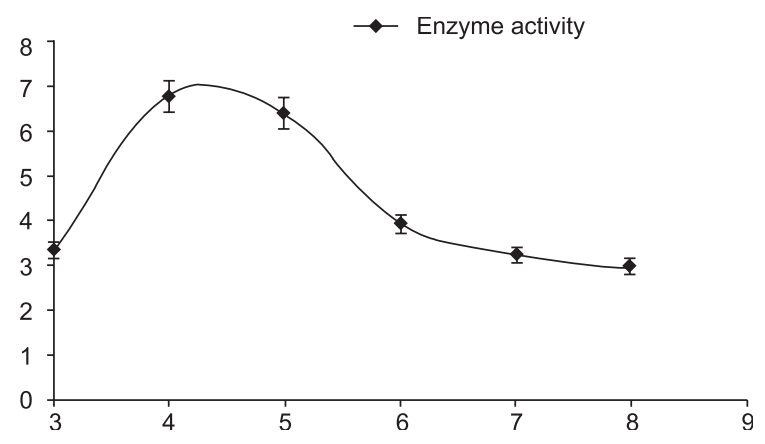

Figure 2. Effect of $\mathrm{pH}$ on cellulase production by T. viride.

Effect of temperature on enzyme production by T. viride

Temperature is a very important factor that influences the cellulase yield by fungi. Maximum enzyme production by $T$. viride was found to be cellulase activity $5.99 \mathrm{U} / \mathrm{ml}$ at $30^{\circ} \mathrm{C}$ (Figure 3). Many researchers have reported different incubation temperatures for maximum cellulase production either in flask or in fermentor studies using Trichoderma spp. The optimal incubation temperature for cellulase production also depends on the strain variation of the microorganism ${ }^{21-22}$.

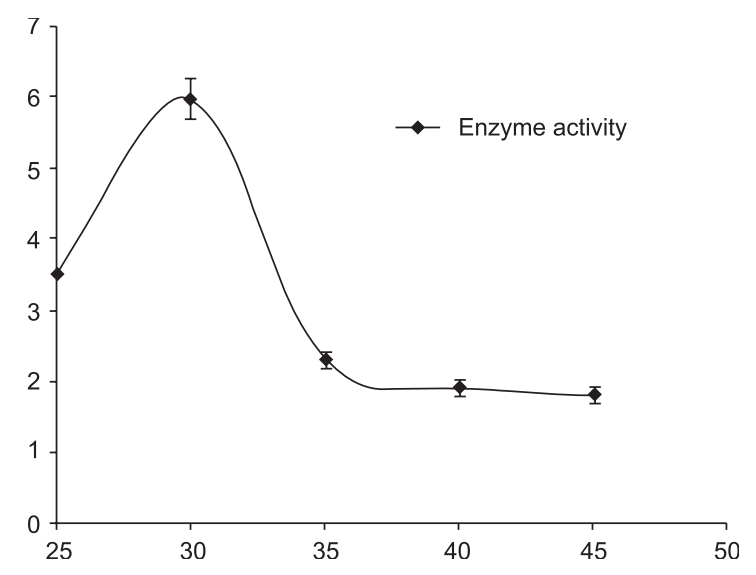

Figure 3: Effect of temperature on enzyme production by T. viride.

Effect of carbon sources on enzyme production by $T$. viride

Data presented in Table 1 show that cellulase production by T. viride was significantly influenced by the type of carbon source. In this study, Carboxymethyl cellulose (CMC) shown to be the most effective as a sole carbon source for cellulase enzyme production. Cellulase production increased with the increases in initial CMC concentration from 0.5 to $1.0 \%$ being cellulase activity $5.52 \mathrm{U} / \mathrm{ml}$ while further increases in concentration of CMC slightly reduced the yield indicating similar result described by Mendals and Reese where they reported that maximum yields of cellulase were obtained on $1 \%$ different carbon substrates using T. viride. ${ }^{23}$ A comparable result was also found on wheat bran as a cheap substrate where the cellulase activity was found $4.74 \mathrm{U} / \mathrm{ml}$ and this result indicates that wheat bran can be used for cost effective cellulase production by $T$. viride.

Table 1. Effect of carbon source on enzyme production by Trichoderma viride.

\begin{tabular}{lcc}
\hline Carbon sources & $\begin{array}{c}\text { Concentration of } \\
\text { carbon sources (\%) }\end{array}$ & $\begin{array}{c}\text { Enzyme } \\
\text { activity (U/ml) }\end{array}$ \\
\hline Lactose & 0.5 & 0.7 \\
& 1.0 & 4.12 \\
CMC & 1.5 & 1.32 \\
& 0.5 & 3.11 \\
Wheat bran & 1.0 & 5.52 \\
& 1.5 & 4.98 \\
Rice bran & 0.5 & 2.8 \\
& 1.0 & 4.74 \\
& 1.5 & 3.34 \\
& 0.5 & 0.39 \\
& 1.0 & 0.65 \\
\end{tabular}




\section{Effect of UV and EtBr mutation}

More than 200 colonies were found on the colony restrictor plates after UV treatment and among them TV-UV20, TV-UV25, TV-UV30 and TV-UV35 were selected for enzyme production as they showed higher activity in plate screening medium visualized by Congo red. Among them TV-UV25 showed best cellulase activity 11.28 U/ml in fermentation medium at $30^{\circ} \mathrm{C}$ and $\mathrm{pH} 4.0$ (Figure 4). On the other hand, more than 230 colonies were found on colony restrictor plates after EtBr treatment and among them TV-EB5, TV-EB9 and TV-EB17 were showed significant increase in cellulase activity in plate screening medium and among them TV-EB17 exhibited highest enzyme activity $14.61 \mathrm{U} / \mathrm{ml}$ in fermentation medium at $30^{\circ} \mathrm{C}$ and $\mathrm{pH} 4.0$ (Figure 5).



Figure 4. Enzyme production by UV treated mutants of T. viride.

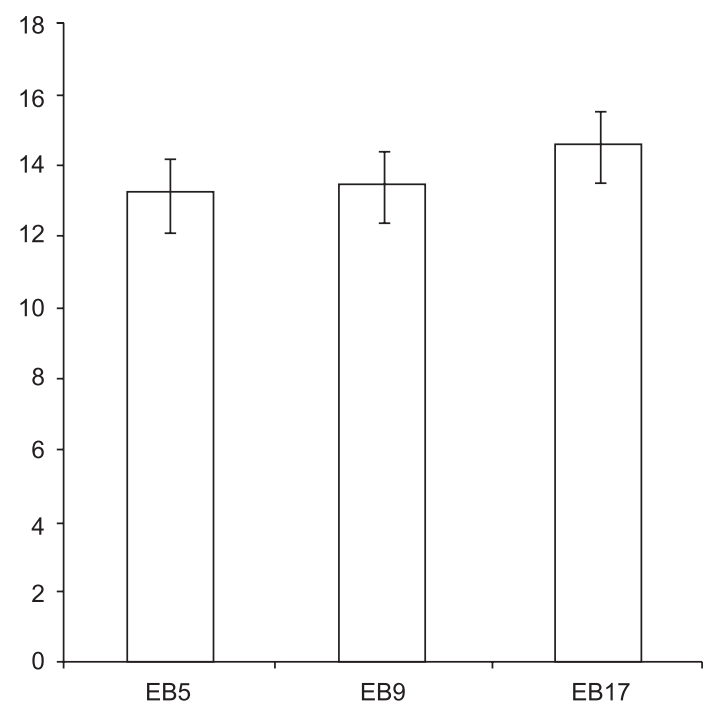

Figure 5. Effect of temperature on enzyme activity

Time course of cellulase production by wild and mutant strains of $T$. viride

Wild T. viride and the mutant strains TV-UV25 and TV-EB17 were cultivated in cellulase production medium composed of Mendal's salt solution and 1.0\% CMC at $\mathrm{pH} 4.0,30^{\circ} \mathrm{C}$ and $120 \mathrm{rpm}$ in an orbital shaker. The wild T. viride and mutant TV-UV25 exhibited best cellulase activity $5.52 \mathrm{U} / \mathrm{ml}$ and $11.28 \mathrm{U} / \mathrm{ml}$ respectively after
2 days where as TV-EB17 showed highest enzyme activity 14.61U/ $\mathrm{ml}$ after 3 days (Figure 6).

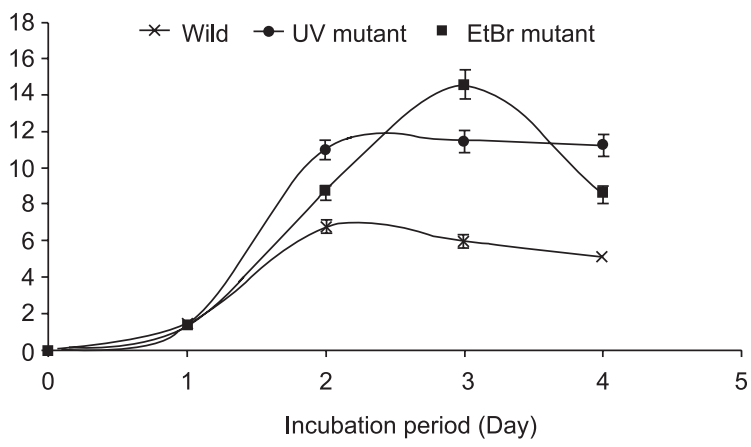

Figure 6: Time course of cellulase production by wild T. viride and mutant strains TV-UV25 \& TV-EB17

Effect of assay temperature on enzymes from wild and mutant strains of T. viride

The enzymes were active in a large temperature range with an optimum at $40^{\circ} \mathrm{C}$ (Figure 5) for all enzymes produced by different mutated strains. The results indicate that the enzymes have approximately same relative activities at various temperature levels and 50\% relative activity for the enzymes were found at $70^{\circ} \mathrm{C}$.

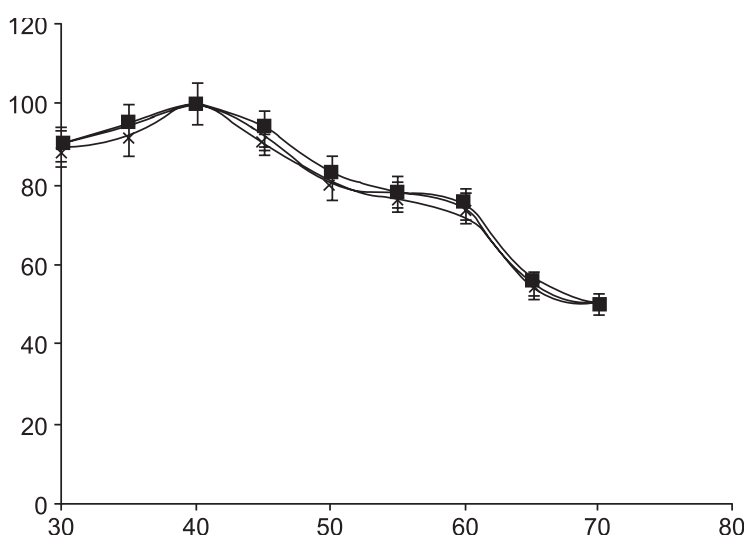

Figure 5. Effect of temperature on enzyme activity

Application of the cellulase from T. viride in bio-polishing After treatment for bio-polishing, the jeans treated with Trichoderma enzyme was found soft, pliable and protruding fiber free as compared to that treated with commercial enzyme. Also the electron microscopy of the samples revealed that enzymes did not degrade the main fiber of the jeans (Figure 6). 

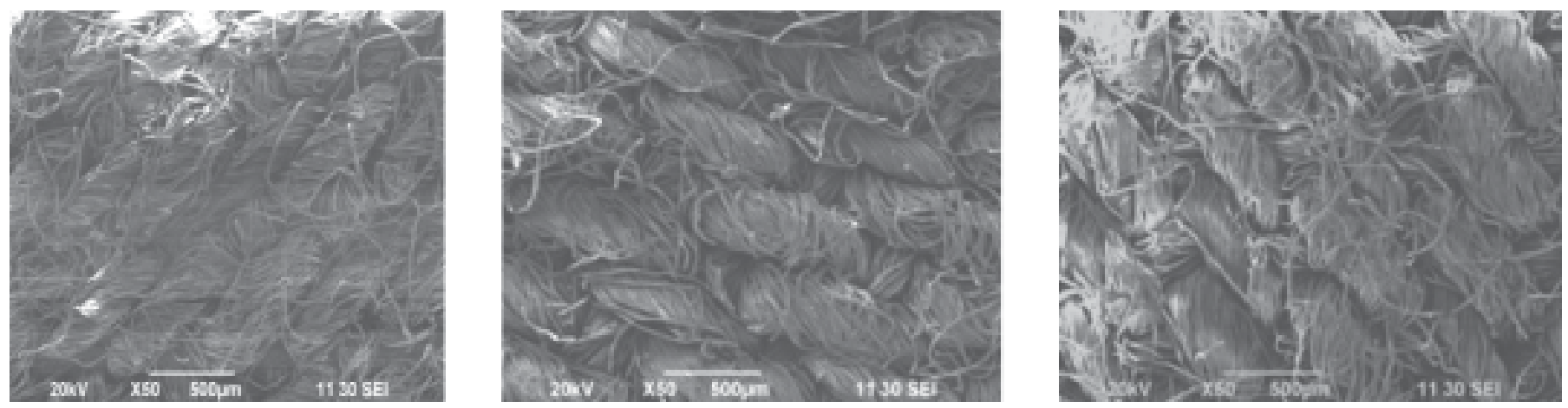

Figure 6. (a) Electron microscopy of jeans Bio-polished by a commercial enzyme (b) Electron microscopy of jeans with no treatment (c) Electron microscopy of jeans Bio-polished by Trichoderma cellulase.

\section{Conclusion}

The wild type Trichoderma viride showed highest cellulase activity $5.52 \mathrm{U} / \mathrm{ml}$ where as the UV treated and EtBr treated mutant showed $11.28 \mathrm{U} / \mathrm{ml}$ and $14.61 \mathrm{U} / \mathrm{ml}$ enzyme activities respectively. The cellulase enzyme from $T$. viride worked very well in biopolishing of jeans in comparison with the commercial enzyme. So, it is concluded that it may be potentially useful for industrial purposes especially for bio-polishing in textile industry.

\section{References}

1. Sukumaran RK, Singhania RR, Pandey A. 2005. Microbial cellulaseProduction, applications and challenges. J Scie and Ind Res. 64: 832-844.

2. Kirk O, Borchert TV and Fuglsan, CC. 2002. In-dustrial enzyme applications. Cur Opi Bio-technol. 13: 345-351.

3. Cherry JR and Fidantsef AL. 2003. Directed evolu-tion of industrial enzymes: An update. Cur Opi Biotechnol. 14: 438-443.

4. Miettinen-Oinonen A, Suominen P. 2002. Enhanced production of Trichoderma reesei endo-glucanases and use of the new cellulase preparations in producing the stone- washed effect on denim fabric. Appl. Environ Microbiol. 68:3956-64.

5. Penttilä ME. 1998. Heterologous protein production in Trichoderma. In: Harman GE and Kubicek CP (eds) Trichoderma and Gliocladium, Enzymes, biological control and commercial applications. 2: 356-383.

6. Nevalainen H, Suominen P and Taimisto K. 1994. On the safety of Trichoderma reesei. J Biotechnol. 37:193-200.

7. Nevalainen $\mathrm{H}$ and Neethling D. 1998. The safety of Trichoderma and Gliocladium. In: Kubicek C and Harman G (eds.) Trichoderma and Gliocladium, Basic biology, taxonomy and genetics. 1: 193-205.

8. Gomes I, Gomes J, Steiner W and Esterbauer H. 1992. Production of cellulase and xylanase by a wild strain of Trichoderma viride. Appl Microbiol Biotechnol. 36: 701-707.

9. Chand P, Aruna A, Maqsood AM, Rao LV. 2005. Novel mutation method for increased cellulase production. J App Microbiol. 98: 318323.

10. Mandels M. 1975. Microbial Sources of cellulase. Biotechnol Bioeng Symp. 5: 81-105.

11. Ghose T K. 1987. Determination of cellulases. Pure App Chem. 59: 257-268.
12. Miller GL. 1959. Use of dinitrosalicylic acid reagent for determination of reducing sugar. An Chem. 31: 426-428.

13. Akinyele JB, Fabunmi AO, and Olaniyi OO. 2013. Effect of variations in growth parameters on cellulase activity of Trichoderma viride NSPR006 cultured on different wood-dusts. Mal J Microbiol. I 9: 193-200.

14. Jadhav AR, Girde AV, More SM, More SB and Khan S. 20113. Cellulase Production by Utilizing Agricultural Wastes. Res J Agric Forestry Sci. 1: 6-9.

15. Ikram-ul-Haq S, Muhammad M J, Zafar S and Tehmina S. 2005. Triggering of beta-glucosidase production in Trichoderma viride with nutritional and environmental control. J App Scie Res. 11: 884-889.

16. Iqbal M N T, Muhammad A, Ishtiaq A and Shahbaz H. 2010. Media optimization for hyper-production of carboxymethylcellulase using proximally analysed agro-industrial residues with Trichoderma harzianum under solid state fermentation. Int J Agro Vet and Med Sci. 4: 47-55.

17. Malik SK, Mukhtar H, Faroo A A and Ikram-Ul-Haq S. 2010. Optimization of process parameters for the biosynthesis of cellulases by Trichoderma viride. Pak J Bot. 42: 4243-4251.

18. Shazia KM, Hamid M, Ammad AF and Ikram UH. 2010. Optimization of process parameters for the biosynthesis of cellulose by Trichoderma viride. Pak J Bot. 6: 4243-4251.

19. Maurya DP, Singh D, Pratap D , Maurya JP. 2012. Optimization of solid state fermentation conditions for the production of cellulase by Trichoderma reesei. J Environ Biol. 33: 5-8.

20. Das M, Banerjee R and Bal S. 2008. Multivariable parameter optimization for the endoglucanase production by Trichoderma reesei Rut C30 from Ocimum gratissimum seed. Braz Arch Biol Technol. 51: $35-41$.

21. Murao S, Sakamoto R and Arai M. 1988. Cellulase of Aspergillus aculeatus. In: Wood WA and Kellog ST (eds.) Methods in Enzymology, 160, Academic Press Inc., London: 275-284.

22. Lu W, Li D and Wu Y. 2003. Influence of water activity and temperature on xylanase biosynthesis in pilotscale solidstate fermentation by Aspergillus sulphurous. Enzyme Microbiol Technol. 32: 305-311.

23. Mandels M and Reese ET. 1957. Induction of cellulase in Trichoderma viride as influenced by carbon sources and metals. J Bacteriol. 73: 269-278. 